\title{
6. CLAY MINERALOGY OF SITES 671 AND 672, BARBADOS RIDGE ACCRETIONARY COMPLEX AND ATLANTIC ABYSSAL PLAIN: PALEOENVIRONMENTAL AND DIAGENETIC IMPLICATIONS ${ }^{1}$
}

\author{
X. Capet, ${ }^{2}$ H. Chamley, ${ }^{2,3}$ C. Beck, ${ }^{2}$ and T. Holtzapffel ${ }^{4}$
}

\begin{abstract}
Three hundred samples of Cenozoic sediments from Sites 671 and 672 were analyzed by X-ray diffraction for their clay mineralogy. In addition, clay particles from selected samples were submitted to microprobe analysis. Throughout the Eocene-Miocene section, the smectite abundance exceeds that of all other minerals. From the lower Pliocene upward, a noticeable increase of illite and chlorite abundance occurs. The presence of thrust faults does not seem to correlate with the composition of the clay species. Quantitative differences in clay mineralogy are mainly due to paleoenvironmental conditions. Prior to the Pliocene, clay mineral assemblages were influenced by climatic and tectonic conditions existing on the adjacent islands and South America. Since the Miocene, the acceleration of the worldwide climatic cooling and the northwestward migration of currents along the South American coast increased the supply of illite and chlorite. Tectonic rejuvenations in the northern part of South America (late Miocene-early Pliocene; late Pliocene-early Pleistocene) were marked by illite and chlorite input and were superimposed on other paleoenvironmental controls.
\end{abstract}

\section{INTRODUCTION}

Following DSDP Leg 78A (Moore, Biju-Duval et al., 1984), the Ocean Drilling Program Leg 110 was devoted to the frontal part of the Barbados Ridge accretionary prism (Fig. 1). Mechanisms of sediment accretion and hydrologic processes related to thrust-faults and basal décollement were studied at six drilling Sites; calcareous nannoplankton, radiolarians, and planktonic foraminifers provided good stratigraphic control. Five of these Sites were drilled in the prism itself, while the sixth is a reference site on the Atlantic abyssal plain (Moore, Mascle, et al., 1987). Site 672 is located $6 \mathrm{~km}$ east where $495 \mathrm{~m}$ of sediments were recovered. Site 671 is located $5 \mathrm{~km}$ west of the deformation front. Hole $671 \mathrm{~B}, 695 \mathrm{~m}$ depth, is the most complete and crossed the décollement zone within the accretionary prism. Detailed sampling was conducted at Site 672 , which crossed a late Eocene to Pleistocene undeformed succession of sediments, and at Hole 671B, which crossed the décollement, several thrust-faults, and a part of the underthrust series.

The purposes of our study were to: (1) determine the clay mineral record and related depositional conditions and settings at Site 672 . (2) investigate possible changes in clay mineralogy within accreted tectonic units by comparing the clay mineral records at Sites 671 and 672, especially by focusing on thrust-fault zones (see Schoonmaker, 1986).

\section{METHODS}

The X-ray diffraction study involved the analysis of 300 samples. Each sample was decalcified by $0.2 \mathrm{~N}$ hydrochloric acid. The excess acid was removed by repeated centrifuging followed by homogenization. The fraction $<2 \mu \mathrm{m}$ was collected by decantation, and oriented aggregates were made on glass slides. The X-ray diffractograms were made using an untreated sample, a glycolated sample, and a sample heated for $2 \mathrm{hr}$ at $490^{\circ} \mathrm{C}$. A Philips 1730 diffractometer (copper $\mathrm{K}$ radiation focused by a

\footnotetext{
${ }^{1}$ Moore, J. C., Mascle, A., et al., 1990. Proc. ODP, Sci. Results, 110: College Station, TX (Ocean Drilling Program).

2 Sciences de la Terre, Université de Lille I, Cité scientifique, 59655 Villeneuve d'Ascq cedex, France.

3 Géologie des bassins sédimentaires, Université Paris VI, 75252 Paris cedex 5.

4 Laboratoire de Géologie, Université d'Angers, Bd Lavoisier, Belle Beille, 49045 Angers cedex, France.
}

quartz curved crystal monochromator) was used at a scan speed of $1^{\circ}$ $2 \theta / \mathrm{min}$, with all instrument settings kept constant for all analyses.

Semi-quantitative evaluations were based on the peak heights and areas of selected clay mineral peaks, assuming that these weighted amounts add up to $100 \%$. The height of the illite and chlorite $(001)$ peaks were taken as references. Compared to these value, smectite, palygorskite, and mixed-layer clay minerals were corrected by multiplying their peak heights from a factor 1.25 in the case of high crystallinity, to a factor 2.5 when poorly crystallinized. By contrast, well-crystallized kaolinite was corrected by a factor of 0.5 . The relative proportions of chlorite and kaolinite were determined from the ratio of peak heights (respectively $3.54 \AA$ and $3.58 \AA$ ): when this ratio is 1 , the amount of chlorite is assumed to be twice that of kaolinite. Final data are given in percentages, the relative error being about $\pm 5 \%$ (Holtzapffel, 1985). The values of illite crystallinity correspond to breadth of the $10-\AA$ peak at half-height measured in $1 / 10^{\circ} \theta$ after glycolation. The relative abundance of smectite corresponds to the $18-\AA$ over $10-\AA$ peak heights ratio measured on the glycolated sample. Both these measurements are made on the X-ray diagram obtained on the glycolated sample.

The micro-geochemical analyses of smectites were made with a CAMEBAX microprobe. The following elements are analyzed by means of their $\mathrm{K}$ rays: $\mathrm{Si}$ and $\mathrm{Ca}$ by reference to andradite, $\mathrm{Al}$ and $\mathrm{Na}$ by reference to albite, $\mathrm{K}$ by reference to orthose, $\mathrm{Fe}^{3}+, \mathrm{Mg}$, and $\mathrm{Ti}$ by reference to pure oxides. The fraction $>2 \mu \mathrm{m}$ was collected in the same way as for fabrication of oriented aggregates; $0.1 \mathrm{~g}$ of this dry fraction was diluted in $10 \mathrm{~mL}$ of permuted water and $2 \mathrm{~mL}$ of this solution were mixed with $10 \mathrm{~mL}$ of butylamin before being dispersed with ultrasonic waves. A drop of the preparation was deposited on a graphitic support. After it dried, a carbon pellicule was vaporized on the preparation. To reduce miscalculations due to the particle size, 40 analyses were made on the same sample. Results were normalized to $100 \%$ and classified according to their chemical characteristics. Such a process usually resulted in the identification of one or several chemical groups, and averages were used to calculate the chemical formulas. In the case of a continuous variation between two chemical poles in the same group, formulas were calculated for the mean composition and poles (Debrabant et al., 1985).

\section{GENERAL RESULTS OF CLAY MINERAL STUDIES}

The following clay minerals were identified (Figs. 2 and 3): chlorite, illite, random mixed-layer minerals (illite-smectite and chlorite-smectite), smectite, kaolinite, palygorskite, and pyrophyllite. Variable amounts of associated minerals were detected within the clay-size fraction: quartz, feldspars, amphi- 


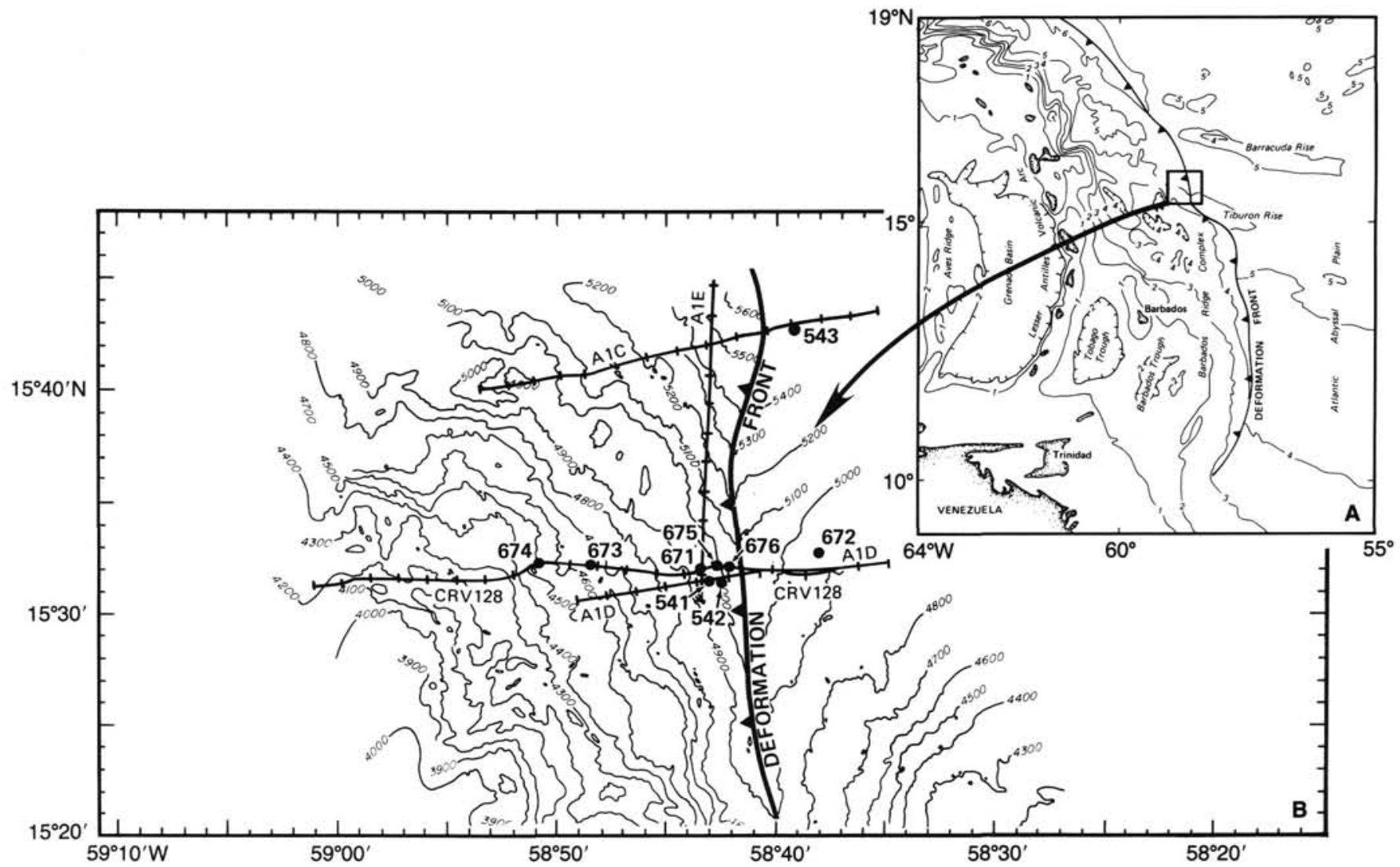

Figure 1. Location of drill sites of Leg 78A and Leg 110 in the Barbados accretionary complex (modified from Mascle, Moore, et al., 1988).

\begin{tabular}{|c|c|c|}
\hline \multicolumn{3}{|c|}{ LITHOLOGY } \\
\hline $\begin{array}{l}\text { W" Volcanic } \\
\text { Aslı }\end{array}$ & $E=-3$ Clay & Sand \\
\hline $\begin{array}{ll} & \text { Calcareous } \\
\end{array}$ & Mudstone & Silt, \\
\hline 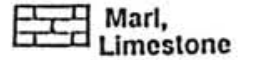 & \begin{tabular}{|l|l} 
Siliceous \\
Mudstone
\end{tabular} & \\
\hline \multicolumn{3}{|c|}{ CLAY MINERALOGY } \\
\hline Chlorite & 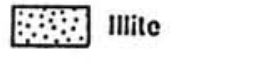 & QDI Mixed layer \\
\hline MIIV Mixed layer & Smectite & 28 Palygorskite \\
\hline Kaolinite & Pyrophyllite & \\
\hline \multicolumn{3}{|c|}{ ASSOCIATED MINERALS } \\
\hline $\begin{array}{l}\text { A: Amphibole } \\
\text { F: Feldspar } \\
\text { L: Lepidocrosite } \\
\text { Q: Quartz }\end{array}$ & $\begin{array}{l}\text { An: Analcite } \\
\text { Gi: Gibbsite } \\
\text { O: Opal CT }\end{array}$ & $\begin{array}{l}\text { C: Clinoptilolite } \\
\text { Go: Gocthite } \\
\text { P: Pyroxene }\end{array}$ \\
\hline rare $\square$ & common & abundant $\mathbf{\square}$ \\
\hline
\end{tabular}

Figure 2. Graphic symbols, used for lithologic description and for clay minerals or associated minerals.

boles, pyroxenes, opal-CT, gibbsite, lepidocrocite, goethite, clinoptilolite, and analcite.

The clay mineral logs at Sites 671 and 672 show the absence of appreciable diagenesis due to depth of burial. Smectite, a mineral unstable in deep diagenetic zones, is very abundant in the deepest sediments recovered. Moreover, illite crystallinity is lower in more buried sediments than in overlying deposits. The amounts of mixed-layer clay minerals, which could represent intermediate products in the diagenetic evolution of smectite to illite (Dunoyer de Segonzac, 1969), are small.

\section{CLAY MINERAL STRATIGRAPHY AT SITE 672 (HOLE 672A)}

The sediment succession at Site 672 is considered a reference because tectonic and hydrologic effects are weak when one moves away from the deformation front. The incipient décollement horizon (early Miocene, Cores 110-672A-21X through -23X) constitutes an exception, as scaly fabric was observed and high fluid circulation was demonstrated by pore-water analysis (Moore et al.,1987; Blanc, et al., 1988; Gieskes et al., in press).

The lithology at Site 672 is shown schematically in Figure 3, and summarized as early Eocene siliceous claystone and mudstone, middle and late Eocene claystone interbedded with calcareous fine-grained turbidites and silty-sandy contourites, Oligocene claystone interbedded with calcareous fine-grained turbidites, early and middle Miocene siliceous clay, and Pliocene and Pleistocene calcareous mudstone and marl. The late Miocene to Pleistocene section contains numerous volcanic ash layers.

The clay mineral record at Site 672 (Fig. 3 and Fig. 4) shows no dramatic vertical trends or rapid changes along the sedimentary column. The following observations were made from the bottom to the top of the hole, which allows us to define seven mineralogic units or subunits (Fig. 4):

From the lower to middle Eocene part of the section (mineralogical Unit 1) there is a decrease in the kaolinite content (from 
35 to $5 \%$ of the clay fraction, Cores $110-672 \mathrm{~A}-49 \mathrm{X}-$ and $-48 \mathrm{X}$ ). Chlorite is absent, illite is present in low amounts (3-7\%), and smectite is abundant (60-90\%). Palygorskite occurs in significant amounts at the very bottom of the section.

From the middle Eocene to the lowermost upper Eocene (mineralogical Unit 2), the composition is rather uniform and similar upto the top of Unit 1, except for the appearance of trace amounts of chlorites (Cores 110-672A-43X to -41X).

The late Eocene to lowermost early Oligocene sediments (mineralogical Unit 3a) comprise low amounts of palygorskite. Smectite constitutes a particularly abundant species $(50-80 \%)$. Kaolinite $(10-40 \%)$ and illite $(5-20 \%)$ display changing amounts. Chlorite $(0-10 \%)$ and irregular mixed-layer minerals $(0-5 \%)$ are present in minor quantities. Late Eocene to early Oligocene (mineralogic Unit $3 \mathrm{~b}$ ) clay mineral assemblages show a composition similar to those described below but they do not contain palygorskite. In the late Oligocene to the early-middle Miocene samples (mineralogical Unit 3c), the kaolinite abundance decreases; this decrease is balanced by an increase of smectite. The early-middle Miocene passage (Cores $110-672 \mathrm{~A}-20 \mathrm{X}$ to $-19 \mathrm{X}$ ) is marked by decreases in both illite and chlorite.

From middle Miocene to lower Pleistocene (mineralogic Unit $4 \mathrm{a}$ and $\mathrm{b}$ ), the smectite abundance decreases from 85 to $30 \%$, whereas other clay minerals increase in the following way: $\mathrm{Ka}$ olinite from 3 to $25 \%$, illite from 7 to $30 \%$, and chlorite from 0 to $10 \%$. Random mixed layers occur almost everywhere in small amounts. The upper Miocene-lower Pliocene and the upper Pliocene-lower Pleistocene boundaries display local increases of illite and chlorite abundance.

\section{DISCUSSION}

The clay mineral log at Site 672 is summarized in Figure 5. These mineralogical units generally do not coincide with the boundaries of lithological units. In addition, the clay mineral variations observed in mineralogical Unit 3 (expecially the late Eocene-Oligocene interval) do not correlate with the detailed lithological changes recorded within this interval (Mascle, Moore, et al., 1988), and Dolan et al., this volume). There is no systematic correlation between the clay mineral assemblages and the presence or absence of turbiditic layers or of volcanic layers.

The general results resemble those obtained by Pudsey (1984) and Latouche and Maillet (1984), who examined sedimentary materials from DSDP Leg 78A. Our interpretations take into account these previous studies, which concerned the general distribution of clay minerals in sediments and in present-day soils and sediments of the Caribbean region. As there is no evidence for authigenesis of clay minerals at Site 672 , clay minerals are considered to be derived mainly from weathering and erosion processes in adjacent exposed areas (Biscaye, 1965; Chamley, $1979,1981)$. They can, therefore, indicate the geographic origin, the source rock types, and the conditions under which the soils evolved. Kaolinite is considered to result mainly from weathering under hot, very humid, and leaching climate. Smectite develops especially in vertisols under warm temperature and seasonally-alternating humidity (Paquet, 1970). The presence of volcanic material favors the formation of smectites. Under hydrolyzing conditions, illite, chlorite, and random mixed-layer clays result from the direct erosion of rocks, suggesting a tectonic rejuvenation. Palygorskite chiefly proceeds from the reworking of chemical sediments formed in coastal basins (Millot, 1964; Chamley, 1979).

Since the work of Delany et al. (1967) and Griffin and Goldberg (1969), various authors have performed clay mineral studies in the Caribbean region. Julius and Pons (1972) showed that smectite and kaolinite are the only clay minerals in soils from Martinique. Studies of present-day marine deposits bordering the Lesser Antilles (Pautrizel and Pons, 1981), Guiana (Jantel,
1982), and the outlets of the Orinoco and Amazon rivers (Gibbs, 1977; Eisma et al., 1978; Bouysse et al., 1980) indicate that illite and chlorite originate from the northern part of South America. Once in the sea, these minerals are transported toward the northwest by currents moving along the continental shelf (Guiana Currents) as well as by deep-water currents (Antarctic Bottom Water-AABW) (Fig. 6). Illite and chlorite, therefore, are mixed with the clay minerals produced locally in the vicinity of the Lesser Antilles Arc (kaolinite and smectite).

\section{Mineralogical Unit 1, Early Eocene and Early Middle Eocene}

Clay assemblages are mainly represented by large amounts of smectite and kaolinite, which commonly form in the soils of equatorial and tropical humid regions (Millot, 1964; Tardy, 1969). Moreover, the volcanogenic rocks that compose the islands of the Lesser Antilles Arc produce abundant smectite by weathering. The small amounts of the so-called primary minerals (illite and chlorite) suggest a period of tectonic stability favoring the development of smectite in poorly drained soils. The decrease of kaolinite during this period indicates a diminution of leaching processes, which could result from a peneplenation of terrestrial reliefs. The snall amounts of quartz can also be related to these facts. The presence of clinoptilolite in association with opal-CT probably results from early diagenesis of biogenic silica.

\section{Mineralogical Unit 2, Middle Eocene}

The appearance of chlorite and the slight increases of illite and kaolinite abundances can be tied to the tectonic phase that affected northern Venezuela (Stéphan, 1985; Beck, 1986; Beck et al., this volume). The fairly small modification in the mineral percentages may be due to mixing with locally derived clay minerals (kaolinite and smectite) in the vicinity of the Lesser Antilles Arc, and also to the fact that the tectonic phase was a subaqueous overthrust, which do not give way to noticeable erosion processes.

\section{Mineralogical Subunit 3a, Late Eocene to Early Oligocene}

This subunit is characterized by the occurrence of fibrous clay minerals that probably were reworked from chemically-concentrated marginal basins. An increase of kaolinite, followed by an increase of illite and chlorite, likely result from a tectonic renewal on land, as documented by onshore studies (Stéphan, 1985; Beck, 1986). By the end of the Eocene, northern Venezuela and its margins underwent extensive deformation by strikeslip fault movements, with subsequent formation of pull-apart basins. Clay-mineral data suggest that the tectonic instability continued during the Oligocene and the early Miocene. Palygorskite, which probably formed in such basins under suitable climatic conditions (i.e., hot climate with strong contrast in dry and humid seasons), was reworked and resedimented in the open ocean as a detrital mineral. These strike-slip fault movements (Beck, 1986) did not form noticeable reliefs. This might explain the slight increase of primary minerals reworked from substrates relative to what is usually recorded during tectonic phases. In addition, warm-humid conditions during late Paleogene times did not favor the erosion of illite and chlorite, but allowed the pedogenic formation of kaolinite, which was reworked from the well-drained upstream areas where it formed.

\section{Mineralogical Subunit 3b, Early Oligocene}

This subunit, marked by the absence of palygorskite and by an increase of kaolinite, illite, and chlorite, suggests a development of erosion processes. This is probably related to the general subsidence, leading to the infilling of large molassic basins in the foothills of northern South America and Trinidad (Stéphan, 1985; Beck, 1986; Beck et al, this volume). 


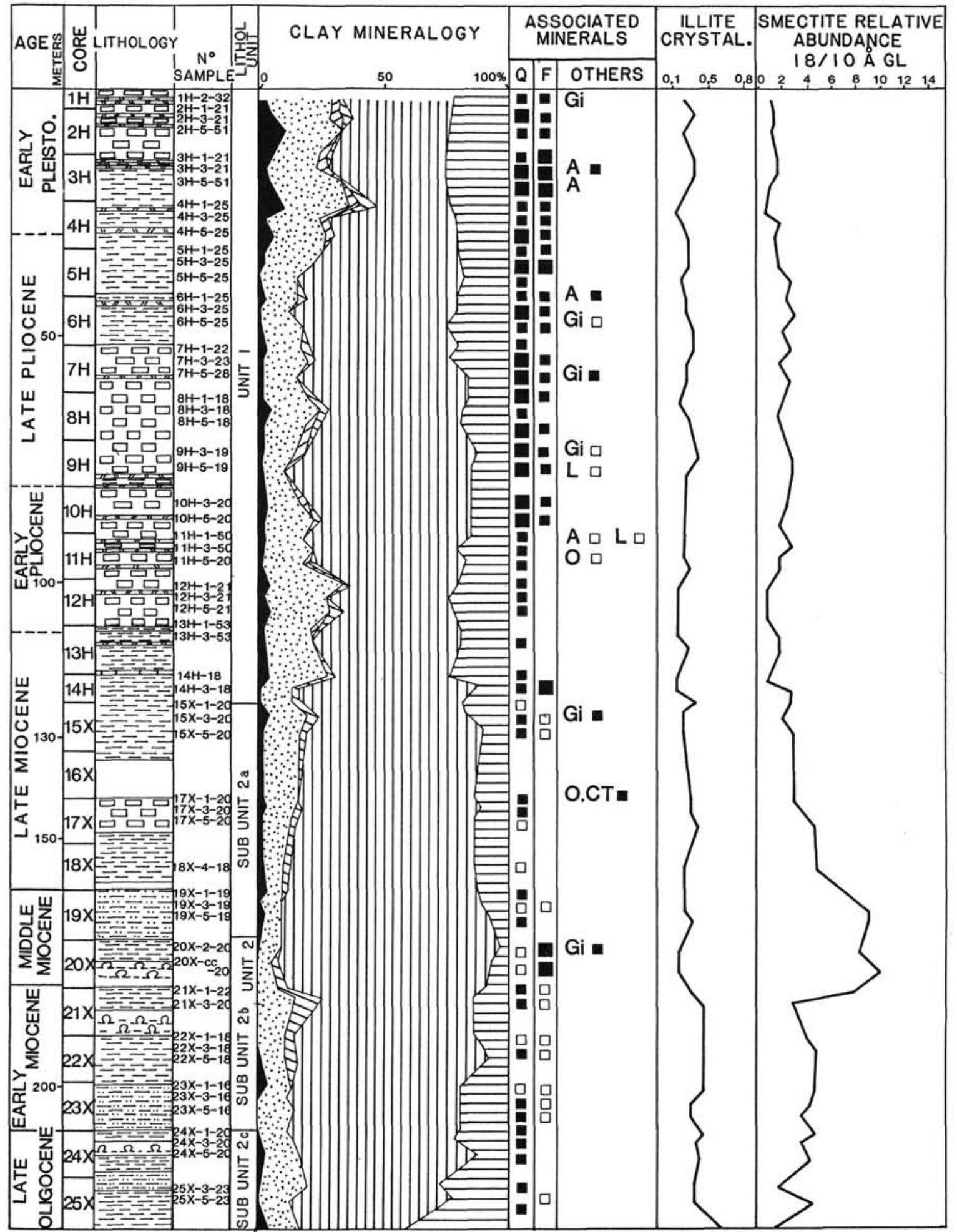

Figure 3. Clay mineral data at Site 672 (Hole 672A) (see Fig. 2 for symbol explanation).

\section{Mineralogical Subunit 3c, Late Oligocene to Early Miocene}

This subunit displays a decrease of kaolinite abundance and the disappearance of chlorite, which could be related to the end of tectonic activity in northern South America and on its margins. The persistence of illite nevertheless suggests the continuation of noticeable erosion processes. This clay mineral could be indicative of continental tectonic rejuvenation or of new inputs either derived from non-equatorial regions or formed in high-altitude and cold-climate conditions despite the equatorial latitude.

Mineralogical Subunit 4a, Middle Miocene to Late Miocene

This subunit is first characterized by an increase in smectite content, which can result from the development of larger area 


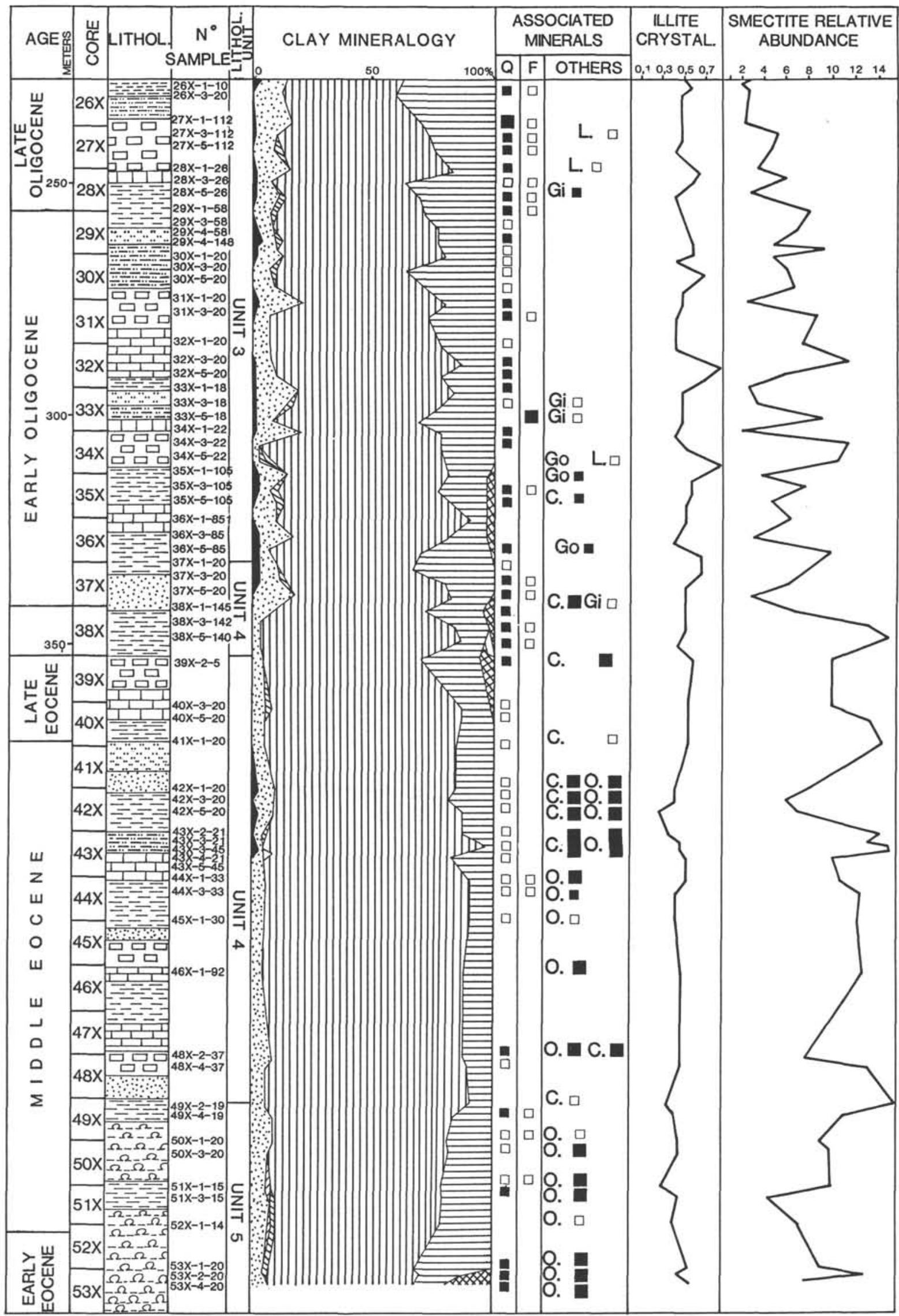

Figure 3 (continued). 


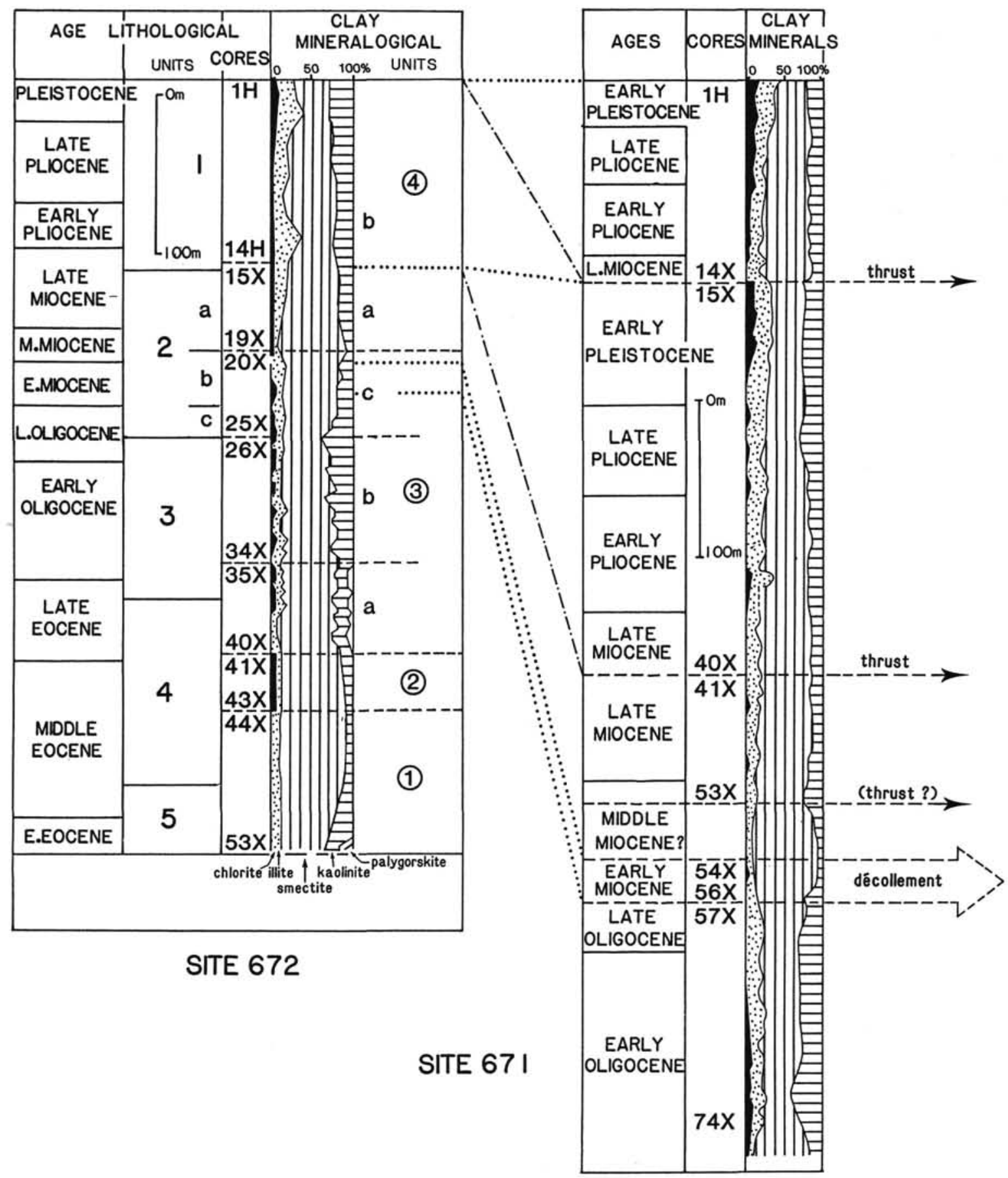

Figure 4. Summarized clay mineral data at Sites 672 and 671 , with the location of lithological and mineralogical units and the location of the thrust fault and décollement zones (see Fig. 2 for symbol explanation).

with poorly drained soils. Such paleogeographic change could be due to the general submergence of the arc during the Miocene (Tomblin, 1975). The extension of explosive volcanism during this period could also have influenced the production of smectite on land.

\section{Mineralogical Subunit 4b, Late Miocene to Early Pleistocene}

In this subunit, clay assemblages differ slightly from those of older sediments. The abundance of smectite diminishes, whereas primary minerals (illite and chlorite) increase and mixed-layer minerals appear. As is the case today, the primary minerals might have originated in the northern part of South America and been transported by surface currents in the central Atlantic. During the Cenozoic, these currents progressively deviated to the northwest and migrated along the northern part of South America (Berggren and Hollister, 1974). This deviation could have been accelerated by the closing of the Panama isthmus in early Pliocene time (Heath and van Andel, 1973). It therefore appears that the fine-grained material eroded from South American mountains and carried to the ocean by the Orinoco and Amazon Rivers contributed to the sedimentation of the Barbados ac- 
cretionary complex. This material formed in high altitudes under cold climate conditions, which explains the relative abundance of illite and chlorite despite the low-latitude location.

Two mineralogical breaks, marked by noticeable illite and chlorite inputs, occur in Unit $4 \mathrm{~b}$ and can be related to a tectonic unstability responsible for a renewal of mechanical erosion. The first break occured at the transition between the late Miocene and the early Pliocene. This may have been a reponse to onshore uplift in the eastern part of the Venezuela-Trinidad chain.

The second break, recorded at the passage from late Pliocene to early Pleistocene, can be related to the tectonic movements indentified in the Andes (Stéphan, 1986). Notice that the two tectonic rejuvenation stages, marked by illite and chlorite outputs, are superimposed on a general increase of illite, chlorite, and quartz from late Miocene to Pleistocene time, which is a widespread phenomena attributed to the general world cooling (Chamley, 1979).

To summarize, clay sedimentation in the late Miocene and early Pleistocene periods was influenced by the general worldwide cooling; in addition, the supply from South America became more important due to both the progressive deviation of central Atlantic surface currents and tectonic activity.

\section{SITE 671 CLAY MINERALOGY, COMPARISON WITH SITE 672, AND HYDROLOGIC IMPLICATIONS}

Site 671 (Hole 671B) sediments were studied with the same density of sampling as at Site 672, to decipher clearly any differences due to thrusting. The detailed results are presented on Figure 4 . We outline here only a few points deduced from comparison with the clay mineral assemblages at Site 672 (Fig. 5).

According to lithostratigraphy, biostratigraphy, and tectonic features, Site 671 was divided into several units separated by thrust faults (Fig. 5) (Moore, Mascle, et al., 1987; Beck et al., 1988; and Mascle, Moore, et al., (1988). At Site 671, the different units show clay mineral assemblages that closely resemble those observed in synchronous periods at Site 672 , despite the tectonic overprint. The décollement horizon at Site 671 displays the same characteristics as the contemporaneous sediments at Site 672: illite, chlorite, and kaolinite are low in abundance, whereas smectite is abundant. The abundance of smectite decreases downhole at both sites.

The differences in the amount of chlorite at Sites 671 and 672 are especially important when considering the second tectonic unit of Hole 672. These differences may result from variations in the sources due to Site 671 being east of Site 672. The underthrust sediments at Site 671 (late Oligocene) have the same clay composition as coeval samples from the reference site. Diagenetic changes do not appear to be responsible for the identified mineralogical differences.

\section{HYDROLOGIC IMPLICATIONS}

At Site 671, pore-water analyses provided clear evidence for intense fluid circulation along fault zones, along the décollement zone, and along a few porous sandy strata (Moore et al., 1987; Blanc, et al., in press; Gieskes et al., in press). As a possible consequence, effects of tectonic and hydrologic conditions on clay minerals, and especially on smectite abundance and nature, can be expected at Site 671. Investigations on this subject were conducted on samples from Leg 78A (Schoonmaker, 1986). Schoonmaker described the specific occurence of saponite, a magnesian trioctahedral smectite, in sediments located above the décollement and along thrust faults described on Leg 78A. Nontronite (dioctahedral smectite) and saponite (trioctahedral smectite) are often described as alteration products of volcanic ashes. Montmorillonite and beidellite (dioctahedral smectites) are more typical of a terrigenous origin.
A criterion commonly used to distinguish di- and tri-octahedral smectites is the position of the $(060)$ peak on powder X-ray diffractograms (Brindley and Brown, 1980). On Figure 7, the high peak to the left is characteristic of dioctahedral smectites (montmorillonite and beidellite). The small peak at $1.52 \AA$ appearing on the two lower diagrams could be attributed to nontronite or to saponite, but this peak occurs only in two samples among 30 analyses of samples located both outside and inside the fault and décollement zones.

To better characterize the chemical nature of smectites, we performed electron microprobe analyses on individual clay particles. Samples were chosen at both Sites 671 and 672. At Site 672 , three samples were chosen: a volcanic bed $(110-672 \mathrm{~A}-11 \mathrm{H}-$ $1,50-55 \mathrm{~cm}$, early Pleistocene), a sample from the incipient décollement level (110-672A-22X-3, 18-20, early Miocene) and one from a zone devoid of volcanic material or thrust (110672A-15X-1, 20-22, late Miocene). Six samples issue from Site 671 , one from a volcanic bed (110-671B-46X-3, 19-22, late Miocene), two from thrust-fault zones (110-671B-14X-3, 20-25, late Miocene, and 110-671B-40X-1, 20-24, Late Miocene), one from a zone without volcanic material or fault (110-671B-48X3, 20-22, late Miocene), and two from the décollement zone (one with volcanic material, 110-671B-55X-5, 20-22, early Miocene; the other without, 110-671B-56X-3, 18-20, early Miocene). In all samples, chemical formulas do not reveal important differences in the composition of smectites (Table 1). The various smectites analyzed belong to the series montmorillonite-beidellite. They do not show a composition which could belong to saponite or nontronite.

Differential thermal analyses of 30 samples chosen inside and outside the fault zones confirm the absence of trioctahedral smectite or nontronite. Therefore, we suggest that the $(060)$ peak appearing on some X-ray diagrams belongs to a mineral other than nontronite or saponite.

The very slight modifications recorded in the chemistry of smectites in décollement or thrust fault zones, and their belonging to the common montmorillonite-beidellite group, suggest that the influence of local tectonics and of fluids migration on clay nature, composition, and chemistry is very low or absent at Site 671. Such a conclusion agrees with heat-flux measurements at Hole 671B, which indicate a thermal gradient much too low to allow diagenetic reactions on smectites $\left(24^{\circ} \mathrm{C}\right.$ at a depth of 500 mbsf) (Mascle, Moore, et al., 1988).

\section{CONCLUSIONS}

According to our analytical techniques, smectites at Sites 672 and 671 do not show obvious diagenetic transformations related either to depth of burial or to the vicinity of the décollement or thrust fault zones.

From the early Eocene to middle Eocene, the clay mineral assemblages are dominanted by smectite; we attribute this mineralogy to tectonic stability on land allowing the development of soils under a warm climate. During the middle Eocene, tectonic activity caused slight increases of chlorite and illite amounts, two minerals reworked from rocky substrates. The introduction of palygorskite during late Eocene-early Oligocene probably reflects the existence of restricted marginal basins whose authigenic sediments were reworked through tectonic unstability in northern Venezuela. From late Oligocene to early Miocene time, a decrease of kaolinite content and an increase of illite and chlorite abundance developed, indicating new terrigenous inputs and probable tectonic rejuvenation. During the Miocene, the general submergence of the Lesser Antilles Arc allowed the development of poorly drained soils rich in smectite. From late Miocene to early Pleistocene time, clay mineral assemblages were influenced by (1) westward deviation of surface currents carrying sediments from the Orinoco and Amazon Rivers and (2) progressive climatic cooling. Two temporary increases of chlorite 


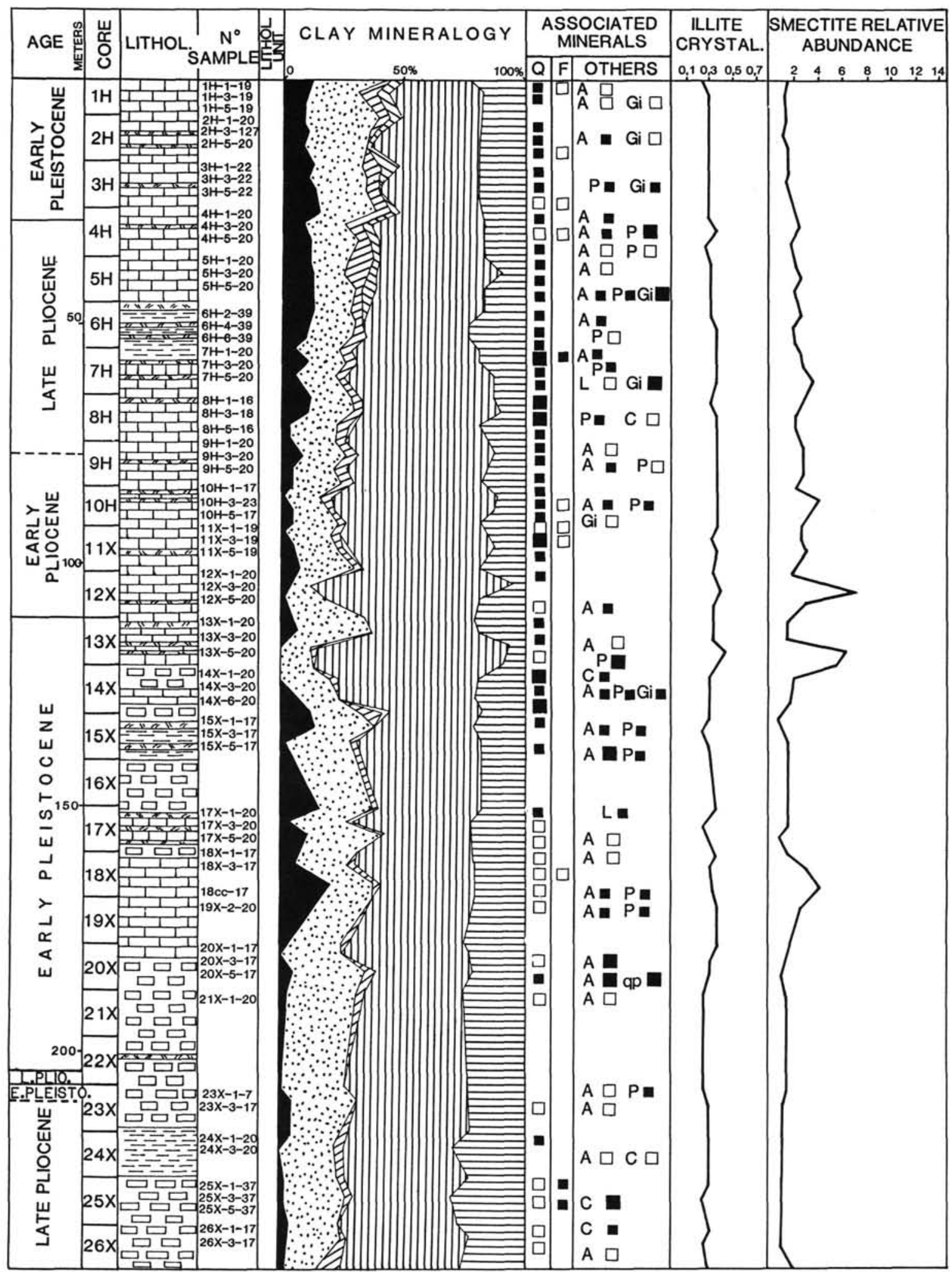

Figure 5. Clay mineral data at Site 671 (Hole 671B) (see Fig. 2 for symbol explanation). 


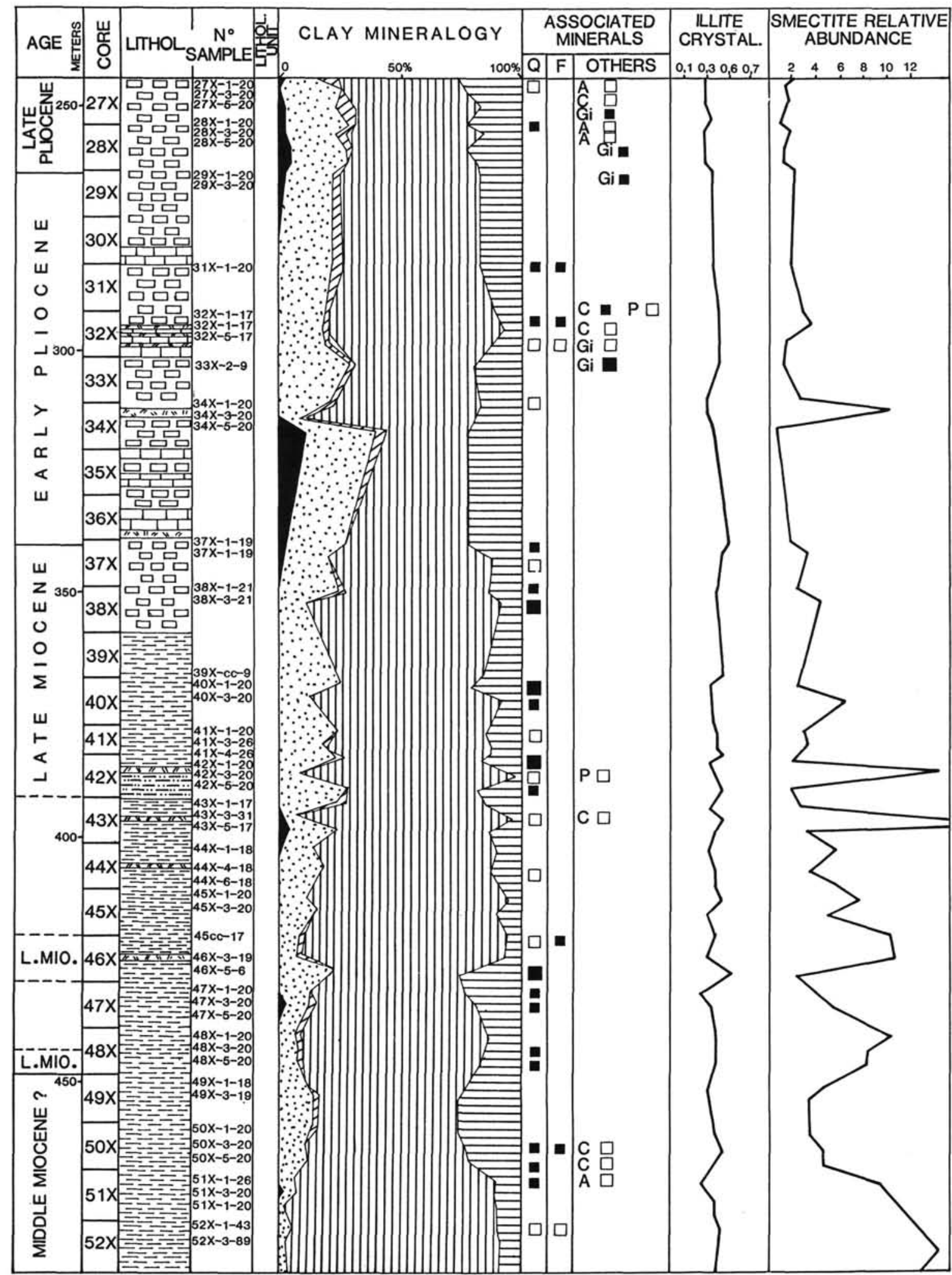

Figure 5 (continued). 


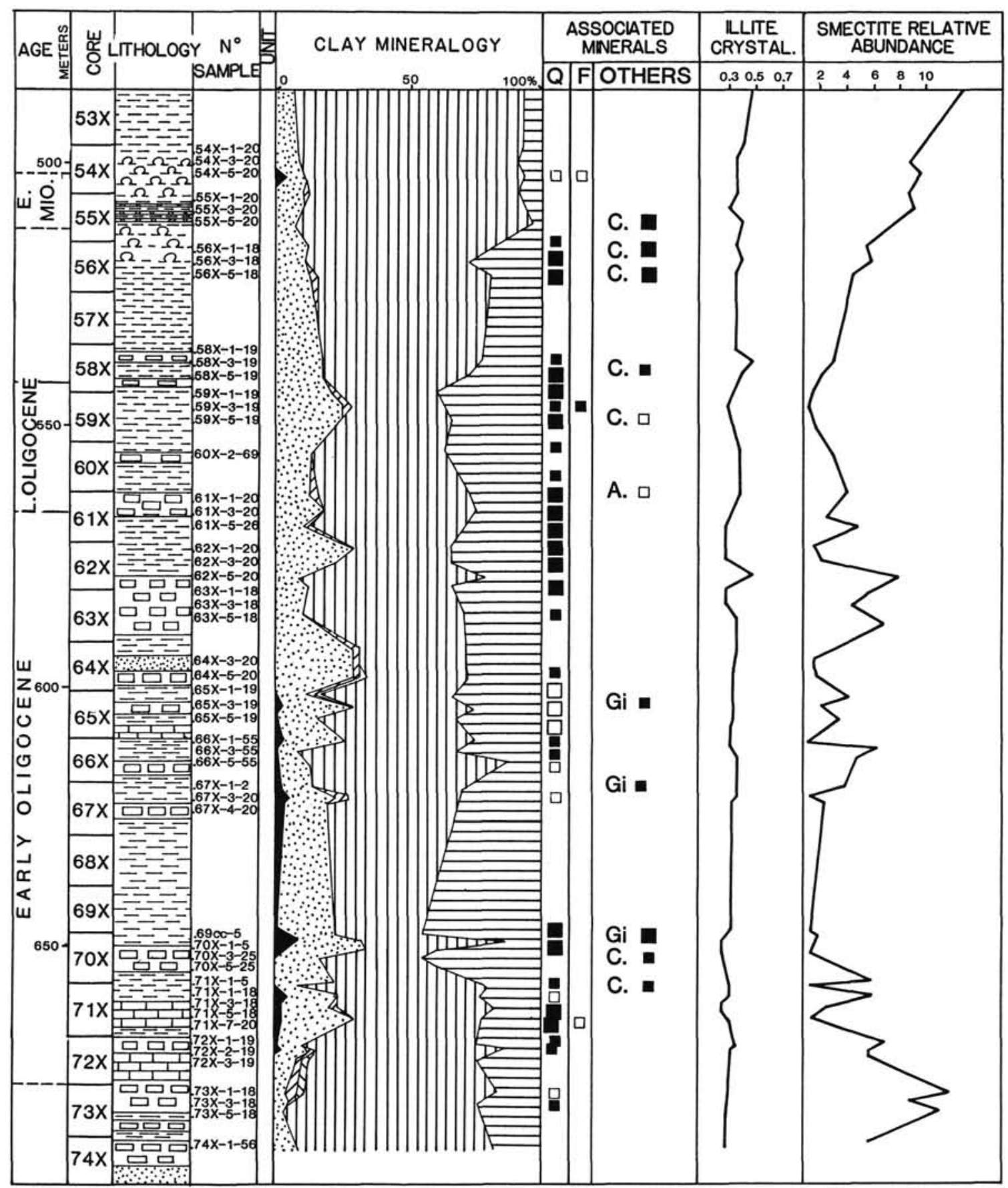

Figure 5 (continued).

and illite during the late Miocene and late Pliocene-Pleistocene were caused by onshore uplifts in the Venezuela-Trinidad Caribbean chain and in the Andes, respectively.

\section{AKNOWLEDGMENTS}

We thank the Ocean Drilling Program for authorizing mineralogical and geochemical studies on Leg 110 samples, as well as ODP-France for providing financial support. Technical support was provided by P. Récourt, M. Bocquet, and D. Lemaguer. The manuscript benefited greatly from the comments of $\mathrm{M}$. Underwood and two anonymous reviewers.

\section{REFERENCES}

Beck, C., 1986. Géologie de la Chaine Alpine Caraïbe au méridiende Caracas (Venezuela). Soc. Géol. Nord, 14:1-462.
Beck, C., Blanc, G., Mascle, A., Moore, J. C., Taylor, E., and Leg 110 Scientific Party, 1988. Anatomie et physiologie d'un prisme d'accrétion: premiers résultats des forages du complexe de la ride de la Barbade. Bull. Soc. Géol. France, 4:121-140.

Berggren, W. A., and Hollister, C. D., 1974. Paleogeography, paleobiogeography and the history of circulation in the Atlantic Ocean. In Hay, W. (Ed.), Studies in Paleoceanography, Soc. Econ. Paleontol. Mineral., 20:126-186.

Biscaye, P. E., 1965. Mineralogy and sedimentation of recent deep sea clay in the Atlantic Ocean and adjacent seas and Oceans. Geol. Soc. Am. Bull., 76:803-832.

Blanc, G., Gieskes, J. M., Vrolijk, P., Mascle, A., Moore, J. C., Taylor, E., and Leg 110 Scientific Party, 1988. Advection des fluides interstitiels dans les séries sédimentaires du complexe d'accrétion de la Barbade (Leg 110 ODP). Bull. Soc. Géol. France, 8:453-460. 
Bouysse, P., Vairon, P., and Zeegers, H., 1980. Géochimie des sédiments superficiels du plateau continental de la Guyanne française. Bull. Inst. Géol. Bassin Aquitaine, 28:92-114.

Brindley, G. W., and Brown, G. (Eds), 1980. Crystal structures of clay minerals and their X-ray indentification. Min. Soc. London Monogr., 5.

Chamley, H., 1979. North Atlantic clay sedimentation and paleoenvironment since the late Jurassic. In Talwani, M., Hay, W. and Ryan, W.B.F. (Eds), Deep Drilling Results in the Atlantic Ocean. Continental Margins and Paleoenvironment: Am. Geophys. Union: 342360 .

1981. Long-term trends in clay deposition in the ocean. Oceanol. Acta, SP3:105-110.

Debrabant, P., Delbart, S., and Lemaguer, D., 1985. Microanalyses géochimiques de minéraux argileux. Application à l'étude de quelques sédiments prélevés en Atlantique Nord, à la base des forages du DSDP. Clays Clay Miner., 20:125-145.

Delany, A. C., Parkin, D. W., Griffin, J. J., Goldberg, E. D., and Reimann, B.E.F., 1967. Airborne dust collected at the Barbados. Geochim. Cosmochim. Acta, 31:885-909.

Dunoyer de Segonzac, G., 1969. Les minéraux argileux dans la diagenèse; passage au métamorphisme. Mém. Serv. Carte Géol. Alsace Lorraine, 29:1-320.

Eisma, D., Van der Gaast, S. J., Martin, J. M., and Thomas, A. J., 1978. The Orinoco Delta, turbidity, mineralogy and elementary composition. Neth. J. Sea Res., 12:224-251.

Gibbs, R., 1977. Clay minerals segregation in the marine environment. J. Sedimentol. Lett., 47:237-243.

Gieskes, J., Blanc, G., Vrolik, P., Moore, J. C., Mascle, A., Taylor, E., and Leg 110 Scientific Party, in press. Hydrogeochemistry in the Barbados accressionary complex: Leg 110 ODP. Tectonophysics.

Griffin, J. J., and Goldberg, E. D., 1969. Recent sediments of Caribbean sea. Soc. Econ. Paleontol. Mineral. Spec. Publ., 11:258-268.

Heath, G. R., and van Andel, T. H., 1973. Tectonics and sedimentation in the Panama Basin: geologic results of Leg 16, Deep Sea Drilling Project. In Van Andel, T. H., Heath, G. R., et al., Init. Repts. DSDP, 16: Washington (U.S. Govt. Printing Office), 899-913.

Holtzapffel, T., 1985. Les minéraux argileux. Préparation, analyse diffractométrique et détermination. Soc. Géol. Nord, Mém., 12:1-136.

Jantel, D., 1982. Etude de la couverture sédimentaire superficielle de la marge continentale guyanaise [Thèse]. Univ. Bordeaux, France.

Julius, C., and Pons, J. C., 1972. Contribution à l'étude d'une mangrove dans la région de Vauclin (Martinique). Bull. Inst. Géol. Bassin Aquitaine, 12:181-186.

Latouche, C., and Maillet, N., 1984. Evolution of Cenozoic clay assemblages in the Barbados Ridge (Deep Sea Drilling Project Sites 541, 542, 543). In Biju-Duval, B., and Moore, J. C., et al. Init. Repts. DSDP. 78A: Washington (U.S. Govt. Printing Office), 343-356.

Mascle, A., Moore, J. C., et al., 1988. Proc. ODP, Init. Repts., 110: College Station, TX (Ocean Drilling Program).

Millot, G., 1964. Géologie des argiles: Paris (Masson).

Moore, J. C., Biju-Duval, B., et al., 1984. Tectonic synthesis, Deep Sea Drilling Project Leg 78A, structural evolution of offscrapped and underthrust sediment, northern Barbados ridge complex. In BijuDuval, B., Moore, J.C., et al., Init. Repts. DSDP, 78A: Washington (U.S. Govt. Printing Office).

Moore, J. C., Mascle, A., Taylor, E., Alvarez, F., Andreieff, P., Barnes, R., Beck, C., Behrmann, J., Blanc, G., Brown, K., Clark, M., Dolan, J., Fisher, A., Gieskes, J., Hounslow, M., McClellan, P., Moran, K., Ogawa, Y., Sakai, T., Schoonmaker, J., Vrolijk, P. J., Wilkens, R., Williams, C., 1987. Expulsion of fluids from depth along a subduction-zone décollement horizon. Nature, 326:785-788.

Paquet, H., 1970. Evolution géochimique des minéraux argileux dans les altérations et les sols des climats méditerranéens tropicaux à saisons contrastées. Mem. Serv. Carte Géol. Alsace Lorraine, 30:1210

Pautrizel, F., and Pons, J. C., 1981. Modalités de la sédimentation au Quaternaire récent dans la mer des Petites Antilles (Fosse de Gre- nade, Ride des Oiseaux, bassin du Vénézuela). Bull. Inst. Géol. Bassin Aquitaine, 30:239-262.

Pudsey, C. J., 1984. X-ray mineralogy of Miocene and older sediments from Deep Sea Drilling Project Leg 78A. In Biju-Duval, B., Moore, J. C., et al., Init. Repts. DSDP, 78A: Washington (U.S. Govt. Printing Office), 325-342.

Schoonmaker, J., 1986. Clay mineralogy and diagenesis of sediment from deformation zone in the Barbados accretionary wedge (Deep Sea Drilling Project Leg 78A). In Moore, J. C. (Ed), Structural Fabrics in Deep Sea Drilling Project Cores From Forearcs: Geol. Soc. Am. Mem., 166:105-116.

Stéphan, J. F., 1985. Andes et Chaine Caraỉbe sur la transversale de Barquisimento (Vénézuela): évolution géodynamique. In Mascle, A. (Ed), Symp. Géodynamique des Caraibes, 505-530.

Tardy, Y., 1969. Géochimie des altérations. Etude des arènes et des eaux de quelques massifs cristallins d'Europe et d'Afrique. Mem. Serv. Carte Géol. Alsace Lorraine, 31:1-199.

Tomblin, J. F., 1975. The lesser Antilles and Aves Ridge. In Nairn, A.E.M., and Stehli, F. V. (Eds), The Ocean Basins and Margins (Vol. 3): New York (Plenum), 467-500.

Date of initial receipt: 30 March 1988

Date of acceptance: 19 May 1989

Ms 110B-129

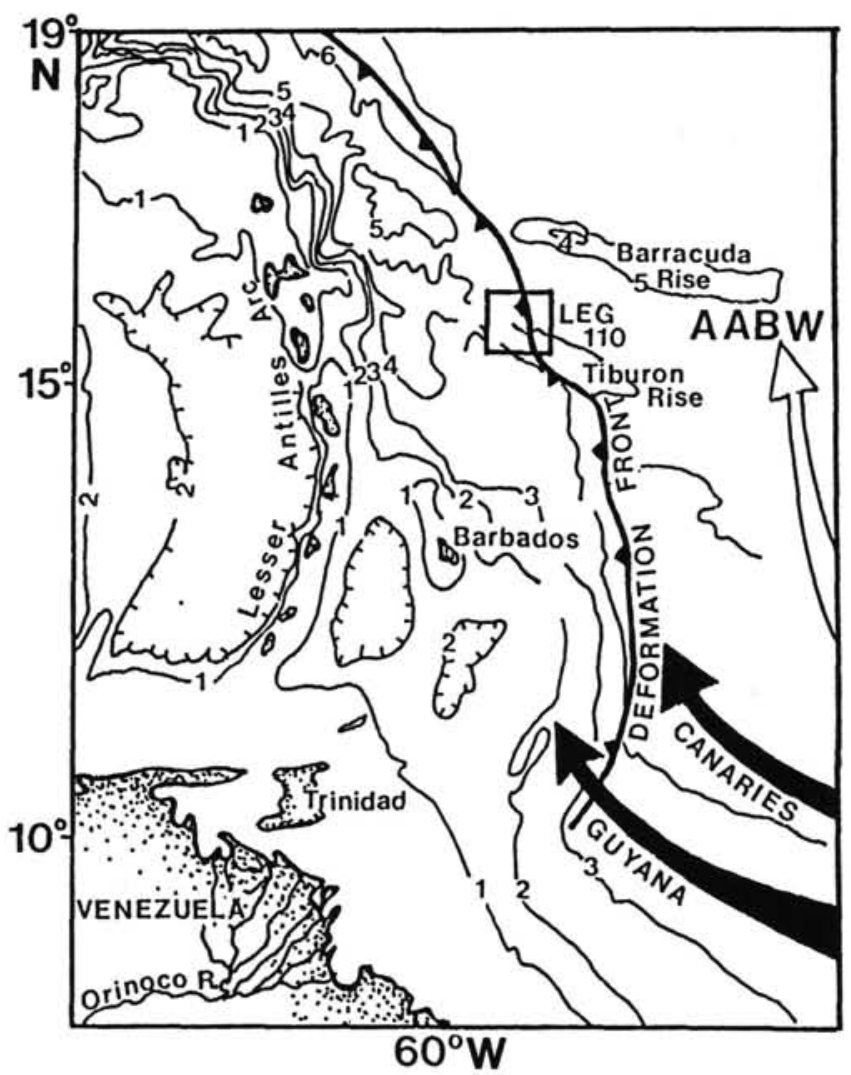

Figure 6. Location of the Leg 110 drilling area in relation to Lesser Antilles Arc, to northern South America, and to present-day surface and bottom currents (modified from Latouche and Maillet, 1984). (white arrow $=$ Bottom Water Current, dark arrow $=$ Surface Currents, AABW = Antarctic Bottom Water.) Depths in kilometers. 


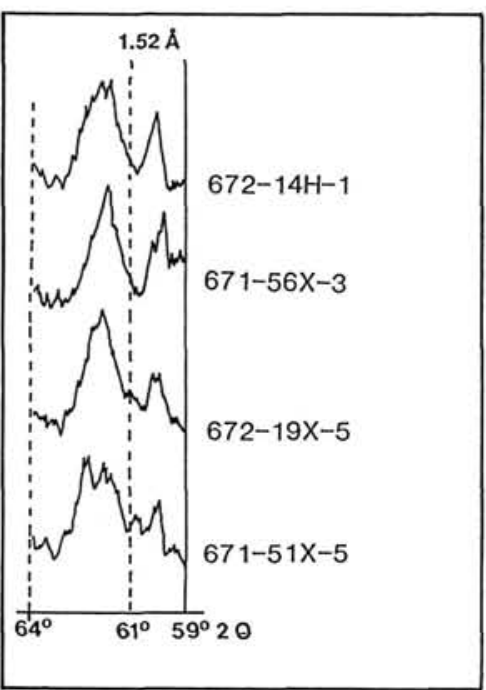

Figure 7. Position of the (060) peak of smectites on powder X-ray diffractograms of selected samples from Leg 110 cores.
Table 1. Chemical formulas of some smectites at Sites 671 and 672 .

\section{Sample}

$672-11 \mathrm{H}-1,50$

$\left(\mathrm{Si}_{3.54} \mathrm{Al}_{0.46}\right)\left(\mathrm{Al}_{1.58} \mathrm{Fe}_{0.28} \mathrm{Mg}_{0.12} \mathrm{Ti}_{0.05}\right)\left(\mathrm{K}_{0.19} \mathrm{Na}_{0.10} \mathrm{Ca}_{0.10}\right)$ $672-15 \mathrm{X}-1,20$

$\left(\mathrm{Si}_{3.35} \mathrm{Al}_{0.65}\right)\left(\mathrm{Al}_{1.52} \mathrm{Fe}_{0.34} \mathrm{Mg}_{0.28} \mathrm{Ti}_{0.03}\right)\left(\mathrm{K}_{0.25} \mathrm{Na}_{0.08} \mathrm{Ca}_{0.07}\right)$ $672-22 X-3,18$

$\left(\mathrm{Si}_{3.75} \mathrm{Al}_{0.25}\right)\left(\mathrm{Al}_{1.05} \mathrm{Fe}_{0.38} \mathrm{Mg}_{0.36} \mathrm{Ti}_{0.04}\right)\left(\mathrm{K}_{0.14} \mathrm{Na}_{0.21} \mathrm{Ca}_{0.06}\right)$ $672-14 \mathrm{X}-3,20$

$\left(\mathrm{Si}_{3.74} \mathrm{Al}_{0.26}\right)\left(\mathrm{Al}_{1.50} \mathrm{Fe}_{0.98} \mathrm{Mg}_{0.62} \mathrm{Ti}_{0.01}\right)\left(\mathrm{K}_{0.25} \mathrm{Na}_{0.25} \mathrm{Ca}_{0.02}\right)$ $\left(\mathrm{Si}_{3.46} \mathrm{Al}_{0.54}\right)\left(\mathrm{Al}_{1.33} \mathrm{Fe}_{0.49} \mathrm{Mg}_{0.45} \mathrm{Ti}_{0.01}\right)\left(\mathrm{K}_{0.20} \mathrm{Na}_{0.24} \mathrm{Ca}_{0.03}\right)$ $\left(\mathrm{Si}_{3.38} \mathrm{Al}_{0.62}\right)\left(\mathrm{Al}_{1.72} \mathrm{Fe}_{0.24} \mathrm{Mg}_{0.16} \mathrm{Ti}_{0.01}\right)\left(\mathrm{K}_{0.18} \mathrm{Na}_{0.31} \mathrm{Ca}_{0.03}\right)$ $671-40 X-1,20$

$\left(\mathrm{Si}_{3.57} \mathrm{Al}_{0.43}\right)\left(\mathrm{Al}_{1.44} \mathrm{Fe}_{0.46} \mathrm{Mg}_{0.24} \mathrm{Ti}_{0.03}\right)\left(\mathrm{K}_{0.23} \mathrm{Na}_{0.15} \mathrm{Ca}_{0.05}\right)$ $672-46 \mathrm{X}-3,20$

$\left(\mathrm{Si}_{3.90} \mathrm{Al}_{0.10}\right)\left(\mathrm{Al}_{1.55} \mathrm{Fe}_{0.26} \mathrm{Mg}_{0.23} \mathrm{Ti}_{0.01}\right)\left(\mathrm{K}_{0.13} \mathrm{Na}_{0.09} \mathrm{Ca}_{0.10}\right)$ $\left(\mathrm{Si}_{3.60} \mathrm{Al}_{0.40}\right)\left(\mathrm{Al}_{1.42} \mathrm{Fe}_{0.31} \mathrm{Mg}_{0.39} \mathrm{Ti}_{0.03}\right)\left(\mathrm{K}_{0.19} \mathrm{Na}_{0.20} \mathrm{Ca}_{0.08}\right)$ $\left(\mathrm{Si}_{3.29} \mathrm{Al}_{0.71}\right)\left(\mathrm{Al}_{1.57} \mathrm{Fe}_{0.39} \mathrm{Mg}_{0.35} \mathrm{Ti}_{0.05}\right)\left(\mathrm{K}_{0.19} \mathrm{Na}_{0.20} \mathrm{Ca}_{0.03}\right)$ $671-48 X-3,20$

$\left(\mathrm{Si}_{3.57} \mathrm{Al}_{0.43}\right)\left(\mathrm{Al}_{1.50} \mathrm{Fe}_{0.34} \mathrm{Mg}_{0.25} \mathrm{Ti}_{0.03}\right)\left(\mathrm{K}_{0.18} \mathrm{Na}_{0.16} \mathrm{Ca}_{0.04}\right)$ $671-55 X-5,20$

$\left(\mathrm{Si}_{3.98} \mathrm{Al}_{0.02}\right)\left(\mathrm{Al}_{1.23} \mathrm{Fe}_{0.38} \mathrm{Mg}_{0.48} \mathrm{Ti}_{0.01}\right)\left(\mathrm{K}_{0.15} \mathrm{Na}_{0.16} \mathrm{Ca}_{0.04}\right)$

$\left(\mathrm{Si}_{3,60} \mathrm{Al}_{0.40}\right)\left(\mathrm{Al}_{1.21} \mathrm{Fe}_{0.41} \mathrm{Mg}_{0.40} \mathrm{Ti}_{0.03}\right)\left(\mathrm{K}_{0.13} \mathrm{Na}_{0.35} \mathrm{Ca}_{0.20}\right)$

$\left(\mathrm{Si}_{3.30} \mathrm{Al}_{0.70}\right)\left(\mathrm{Al}_{1.84} \mathrm{Fe}_{0.22} \mathrm{Mg}_{0.20} \mathrm{Ti}_{0.05}\right)\left(\mathrm{K}_{0.05} \mathrm{Na}_{0.11} \mathrm{Ca}_{0.05}\right)$ 671-56X-3, 18

$\left(\mathrm{Si}_{3,76} \mathrm{Al}_{0.24}\right)\left(\mathrm{Al}_{1.53} \mathrm{Fe}_{0.32} \mathrm{Mg}_{0.40} \mathrm{Ti}_{0.02}\right)\left(\mathrm{K}_{0.33} \mathrm{Na}_{0.16} \mathrm{Ca}_{0.03}\right)$ $\left(\mathrm{Si}_{3.47} \mathrm{Al}_{0.53}\right)\left(\mathrm{Al}_{1.54} \mathrm{Fe}_{0.36} \mathrm{Mg}_{0.27} \mathrm{Ti}_{0.03}\right)\left(\mathrm{K}_{0.18} \mathrm{Na}_{0.17} \mathrm{Ca}_{0.05}\right)$ $\left(\mathrm{Si}_{3.24} \mathrm{Al}_{0.76}\right)\left(\mathrm{Al}_{1.90} \mathrm{Fe}_{0.18} \mathrm{Mg}_{0.15} \mathrm{Ti}_{0.01}\right)\left(\mathrm{K}_{0.01} \mathrm{Na}_{0.08} \mathrm{Ca}_{0.03}\right)$ 